\title{
A CONTRIBUTION TO THE LIVERWORT FLORA OF THE UPPER COURSE OF INDIGIRKA RIVER, EAST YAKUTIA
}

\section{МАТЕРИАЛЫ К ФЛОРЕ ПЕЧЕНОЧНИКОВ ВЕРХНЕГО ТЕЧЕНИЯ Р. ИНДИГИРКА, ВОСТОЧНАЯ ЯКУТИЯ}

\author{
ELENA V. SOFRONOVA ${ }^{1}$ \\ ЕЛЕНА В. СОФРОНОВА ${ }^{1}$
}

Abstract

\begin{abstract}
The list of liverworts of Upper Course of the Indigirka River was first updated in 1980. An annotated list of liverworts collected and reported here includes 65 species. The data on structures associated with reproduction, localities, substrates, habitats, and growth pattern are also provided. Marsupella sprucei is recorded for the first time for Yakutia. In several plant communities, a very small number of liverworts have been collected. Almost all the diversity of species was found to occur along the banks of watercourses, in wet niches of rock-fields and in moist, shaded cracks of rock. On the banks of a small brook, numerous rock outcrops and rock-fields on Tas-Kystabyt Mt. Range, eight rare species were found - Calycularia laxa, Cryptocolea imbricata, Marchantia romanica, Marsupella boeckii, Pseudotritomaria heterophylla, Scapania kaurinii, S. rufidula, S. sphaerifera. Asterella saccata and Mannia fragrans are limited here in their distribution only to steppes. Another rare species Haplomitrium hookeri - is found in the moss community on old rut winter road.
\end{abstract}

Резюме

Приводится аннотированный список печеночников для верхнего течения р. Индигирка, включающий 65 видов. Для каждого вида указано наличие структур, связанных с размножением, выявленные местонахождения, субстрат, местообитания, характер произрастания. Marsupella sprucei впервые приводится для флоры печеночников Якутии. В растительных сообществах отмечено очень небольшое число печеночников. Почти все разнообразие видов обнаружено вдоль берегов водотоков, во влажных нишах курумов и трещинах скал. На хребте Тас-Кыстабыт по берегу одного небольшого ручья и среди скальных обнажений и курумах вдоль ручья найдено восемь редких видов: Calycularia laxa, Cryptocolea imbricata, Marchantia romanica, Marsupella boeckii, Pseudotritomaria heterophylla, Scapania kaurinii, S. rufidula, S. sphaerifera. Asterella saccata и Mannia fragrans произрастают здесь только в степных сообществах. Еще один редкий вид (Haplomitrium hookeri) отмечен в моховом сообществе на колее зимника.

KEYWORDS: flora, liverworts, ecology, Yakutia

\section{INTRODUCTION}

The study area is situated in the Upper Course of the Indigirka River and includes areas near the Ust-Nera settlement and the In'yalinsky Range, located on the left bank of the In'yali River. The hepatic flora of the Indigirka River Basin is very poorly explored. The only data on liverworts for the study area was published by Afonina \& Duda (1980) for the In'yali Creek area, about 80 $\mathrm{km}$ downstream of the Indigirka River from the Ust-Nera settlement. It was based on collections made by O.M. Afonina in the course of a Polar expedition of the Komarov Botanical Institution; this study especially concentrated on tundra-steppe communities occurring on southfacing slopes (Ivanova et al., 2018). This list comprised of 43 liverworts species, mainly from the spurs of the Silyap Range. This present work is based on specimens collected on the left bank of the In'yali River in 2012 from June 30 to July 7 and in the vicinity of the Ust-Nera settlement in 2015 during July 31 to August 7. The resulting list is obviously not exhaustive; however, it includes a number of interesting new records.

\section{STUDY AREA}

The explored territory is located in the upper course of the Indigirka River near the mouth of the Nera and In'yali Rivers. The liverwort specimens were collected in In'yali-Olchan Upland (namely near Ol'chan gold works and in the In'yali River valley, In'yalinsky Range), Mt. Range Tas-Kystabyt (Sarychev), Indigirka River valley up to ca. $10 \mathrm{~km}$ upstream Ust-Nera Settlement, and Nera River valley up to ca. $60 \mathrm{~km}$ from its mouth (Fig. 1, Table 1).

\footnotetext{
1 - Institute of Biological Problems of Cryolithozone SB RAS, Lenina str. 41, Yakutsk, 677980 Russia - Россия 677980, Якутск,
} пр-т Ленина, 41, Институт биологических проблем криолитозоны CO PAH; e-mail: soflena@mail.ru 


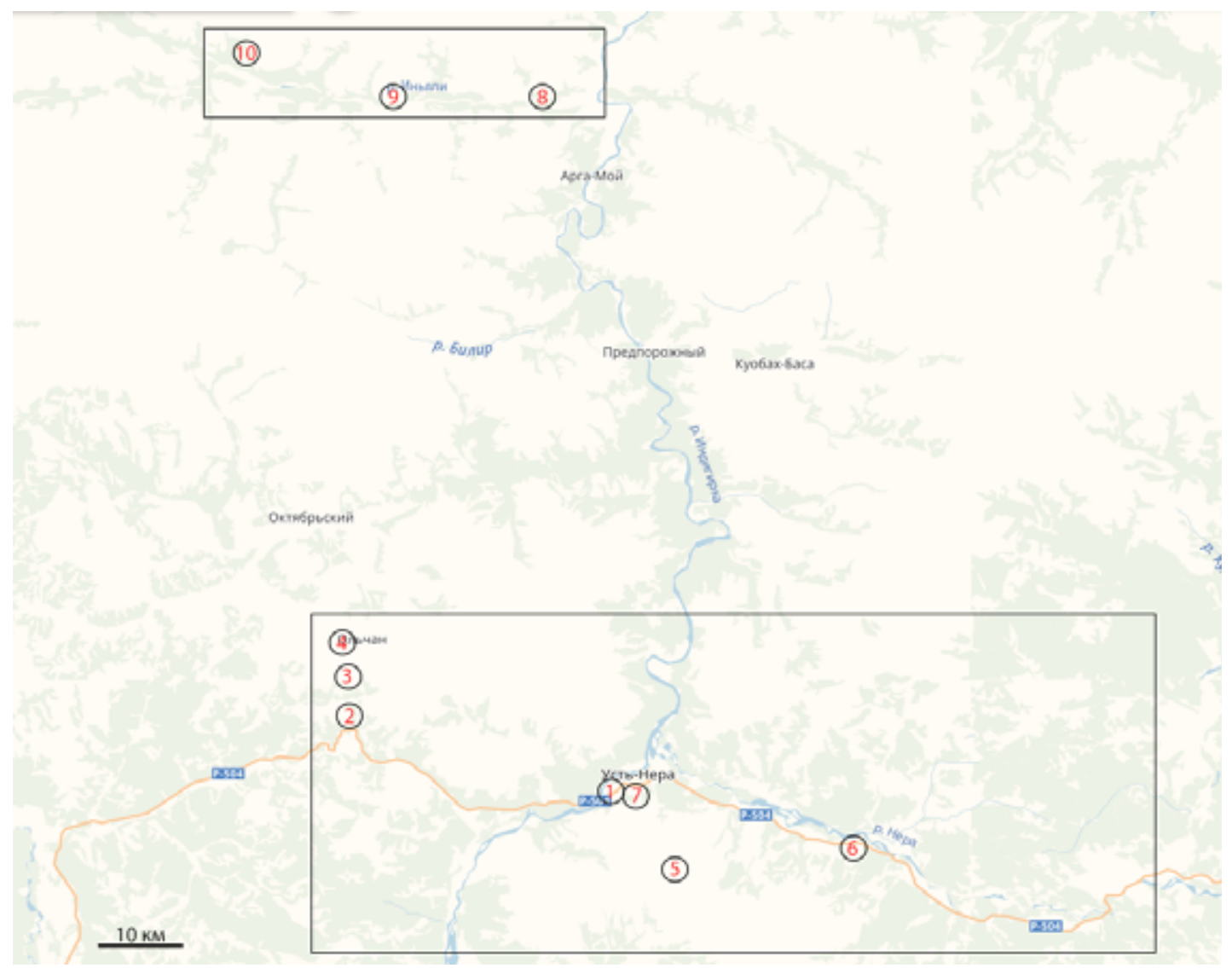

Fig. 1. Collecting localities in the upper course of Indigirka River near Ust-Nera Settlement and In'yali River valley.

\section{Locality}

1. Left bank of Indigirka River at ca. $13 \mathrm{~km} \mathrm{SW}$ of Ust-Nera Settlement

2. Near the Ol'chan Pass at $34 \mathrm{~km} \mathrm{NW}$ of Ust-Nera Settlement

3. Road to Ol'chan at $40 \mathrm{~km} \mathrm{NW}$ of Ust-Nera Settlement

4. Ol'chan gold works

5. $15 \mathrm{~km}$ SE of Ust-Nera Settlement, Taas-Kystabyt Mt. Range near Nelkan pass

6. Nera River valley at ca. $23-55 \mathrm{~km}$ E of Ust-Nera Settlement

7. Right bank of Indigirka River at ca. $3 \mathrm{~km} \mathrm{SW}$ of Ust-Nera Settlement

8. Left bank of the In'ali River, $7 \mathrm{~km}$ from the mouth

9. Left bank of the In'ali River, $25 \mathrm{~km}$ from the mouth

10. Left bank of the In'ali River, $42 \mathrm{~km}$ from the mouth

$\begin{array}{lll}\text { Altitude, m } & \begin{array}{l}\text { Latitude } \\ 625\end{array} & \begin{array}{l}\text { Longitude } \\ 64^{\circ} 32^{\prime}\end{array} \\ 142^{\circ} 58^{\prime} \\ 1100 & 64^{\circ} 37^{\prime} & 142^{\circ} 31^{\prime} \\ 850-900 & 64^{\circ} 39^{\prime} & 142^{\circ} 32^{\prime} \\ 770 & 64^{\circ} 42^{\prime} & 142^{\circ} 35^{\prime} \\ 1230-1600 & 64^{\circ} 27^{\prime} & 143^{\circ} 20^{\prime}\end{array}$

$\begin{array}{lll}500-700 & 64^{\circ} 25^{\prime}-64^{\circ} 30^{\prime} & 143^{\circ} 43^{\prime}-144^{\circ} 21^{\prime} \\ 500-550 & 64^{\circ} 33^{\prime} & 143^{\circ} 11^{\prime} \\ 300-550 & 65^{\circ} 14^{\prime} & 142^{\circ} 59^{\prime} \\ 550 & 65^{\circ} 14^{\prime} & 142^{\circ} 37^{\prime} \\ 650-1100 & 65^{\circ} 17^{\prime} & 142^{\circ} 16^{\prime}\end{array}$

Geologically, the In'yali-Olchan Upland (incl. In'yalinsky Range) is formed mainly by sandstones and siltstones, and rarely limestones of the Jurassic and Triassic periods. A distinctive feature of the Upland is the presence of numerous massifs of igneous rocks and intrusions of the Cretaceous period - numerous small massifs of andesite and basalt, and large intrusions of granites, diorites, etc. (Imaev et al., 2000). The general background of the relief is the middle mountains (1500-1800 $\mathrm{m})$, above which high-mountainous massifs are formed, composed of igneous rocks (2100-2300 m). Tas-Kystabyt Mt. Range (with maximal altitude of $2200 \mathrm{~m}$ ) is formed by the Triassic siltstone, mudstone and sandstone strata sometimes with carbonate nodules, interrupted by large massifs of intrusive and subvolcanic rocks of the andes- ite, basalt, granites etc. of Cretaceous and Jurassic periods. In the area of the Tas-Kystabyt Range manifestations of arsenic, antimony and mercury are noted. The valleys of the Indigirka, Nera and In'yali Rivers in the area of study are composed of alluvial sediments, less often glaciofluvial - pebbles, boulders, gravel, sand, etc. Technogenic fill-up and inwashed pebbles, crushed stone, sand, sandy loam are becoming more common.

Climate of the study area is severely continental. The mean annual temperature in the study area is about $-15^{\circ} \mathrm{C}$; winter lasts more than 7 months, with the number of days with snow cover over 200 ; lowest temperature $-68^{\circ} \mathrm{C}$; highest temperature $33^{\circ} \mathrm{C}$; annual precipitation $225 \mathrm{~mm}$. This area is xeric, with precipitation to evaporation ratio being 0.2-0.15 (Table 2; Ivanova et al., 2018). 

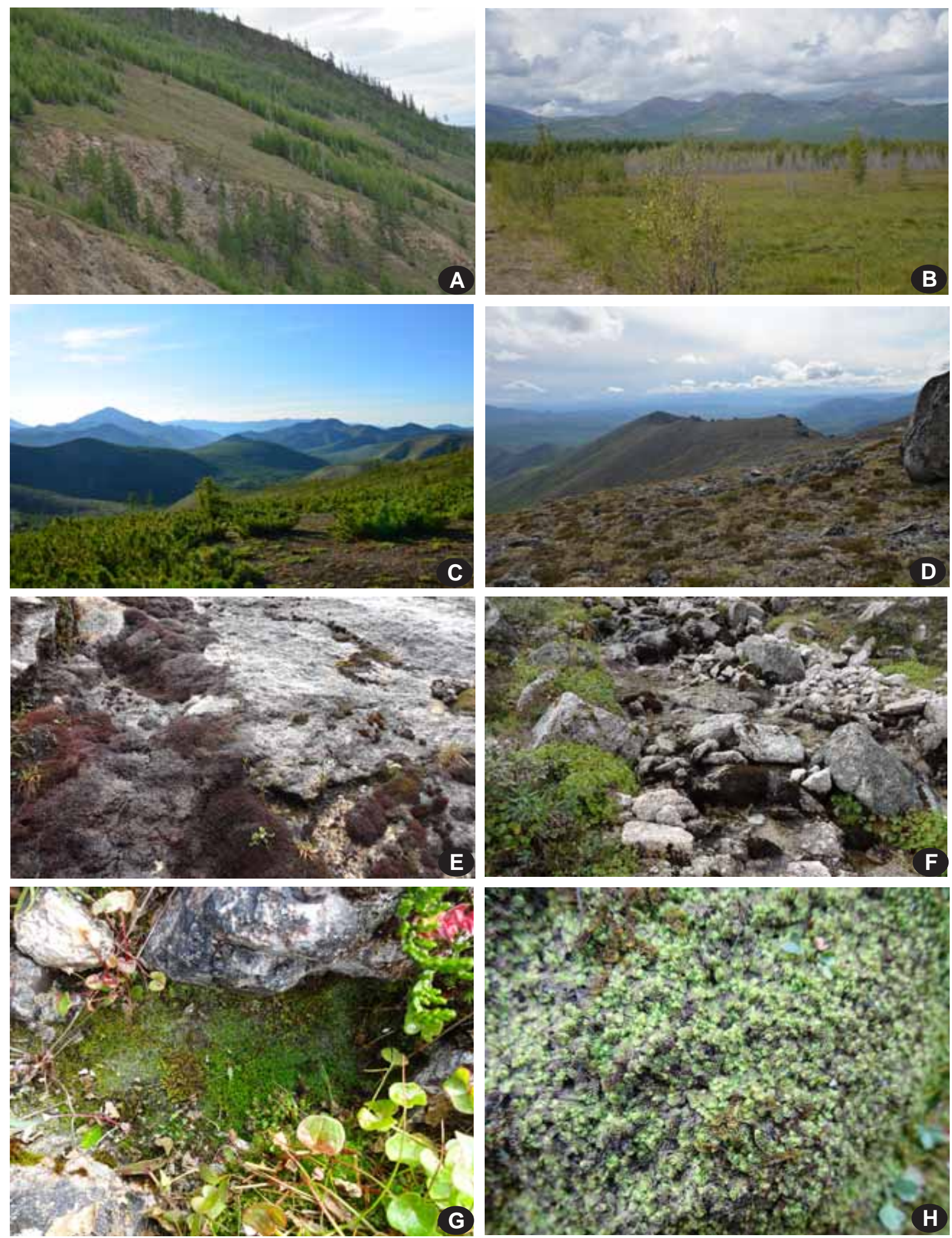

Fig. 2. A view near Ust-Nera Settlement. A: larch forest and steppes community; B: grass mire; C: Pinus pumila community; D: mountain tundra; E: wet rock outcrops; F: bank of small brook on the open slope of Tas-Kystabyt Mt.; G: Anthelia juratzkana, Scapania crassiretis, S. kaurinii and Tritomaria quinquedentata on the bank of brook; H: Schistochilopsis opacifolia and Scapania kaurinii on the bank of brook. 

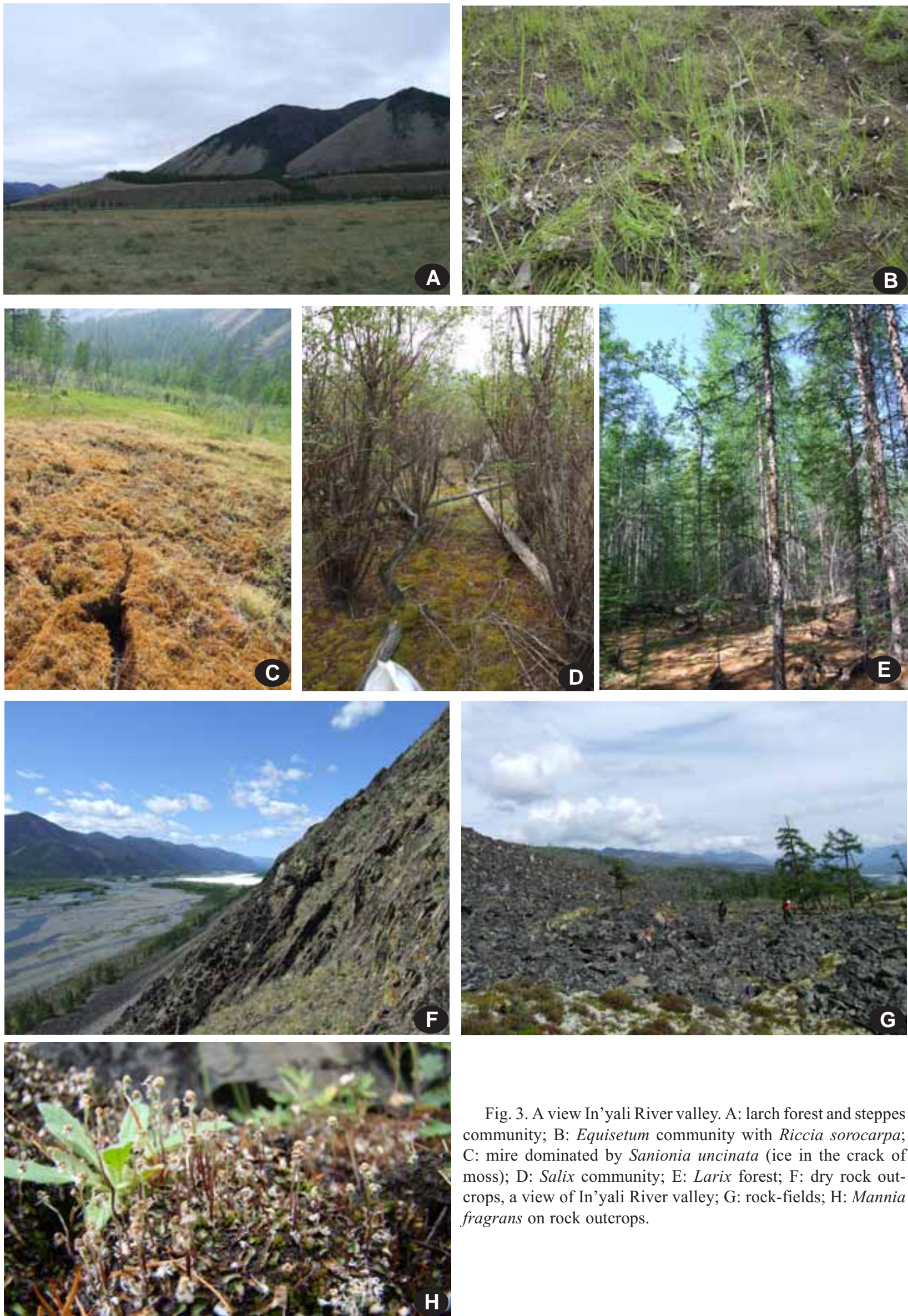

Fig. 3. A view In'yali River valley. A: larch forest and steppes community; B: Equisetum community with Riccia sorocarpa; C: mire dominated by Sanionia uncinata (ice in the crack of moss); D: Salix community; E: Larix forest; F: dry rock outcrops, a view of In'yali River valley; G: rock-fields; H: Mannia fragrans on rock outcrops. 
Table 2. Meteorological data from the nearest meteostations (Izyumenko, 1966, 1968).

\begin{tabular}{llllllll} 
Meteostations & $\mathrm{t}_{\text {ann }}$ & $\mathrm{t}_{\max }$ & $\mathrm{t}_{\min }$ & $\mathrm{t}_{\text {January }}$ & $\mathrm{t}_{\text {July }}$ & $\begin{array}{l}\text { Annual precipitation, } \\
\mathrm{mm}\end{array}$ & $\begin{array}{l}\text { Maximal depth of } \\
\text { snow cover, cm }\end{array}$ \\
Nera & -15.3 & 34 & -68 & -48.5 & 15.5 & 225 & 45 \\
Predporozhnaya & -14.6 & 34 & -67 & -45.6 & 15.7 & 205 & 37 \\
El'gi & -16.6 & - & - & -49.7 & 14.5 & 224 & - \\
Oimyakon & -16.6 & 33 & -71 & -50.0 & 14.5 & 175 & 43 \\
Agayakan & -16.1 & 33 & -67 & -48.4 & 13.9 & 220 & 51 \\
\hline
\end{tabular}

The study area is located in the zone of continuous permafrost, its hydrogeological features affecting vegetation are determined by the water available of the active layer. The latter are formed due to melting of permafrost and the infiltration of precipitation, so the permafrost surface serves as a perforated layer. Additional data on the climate, soils and vegetation of the territory are published by Ivanova et al. (2018).

\section{LIVERWORTS IN VEGETATION COVER}

This area is relatively xeric, and therefore, liverworts have a very limited distribution in the study area. In the larch forests on soil, liverworts are represented mostly by Ptilidium ciliare and Barbilophozia barbata which form large patches (up to 1 sq. m). Other hepatics growing on and among Sphagnum ssp. in Sphagnum-Larix communities and have a minute (up to $1 \mathrm{sq} . \mathrm{cm}$ ) or small (up to 100 sq. cm) cover; these are Cephalozia bicuspidata and $\mathrm{Ca}$ lypogeia muelleriana. Shrub communities of Pinus pumila, Betula divaricata, Alnus fruticosa, Salix spp. are also quite arid. Only Isopaches bicrenatus, Cephaloziella varians (up to 1 sq. m) and Blasia pusilla (few plants) are recorded. All mires in the study area are extremely arid. There are almost no liverworts, even in Sphagnum mires. Only in the grass mires Lophozia ventricosa s.l. (up to 1 sq. m) and Scapania paludicola (few plants) were found. In the mountainous tundra, only Gymnomitrion corallioides, Isopaches bicrenatus, Sphenolobus minutus and Tetralophozia setiformis with a small continuous cover (up to 100 sq. $\mathrm{cm}$ ) were observed. All other species noted here were represented by few plants. Asterella saccata, Mannia fragrans and Riccia sorocarpa are relatively common in the steppes, though they do not form solid patches. In wet anthropogenic places Marchantia polymorpha subsp. polymorpha forms continuous cover up to $1 \mathrm{~m}$. On soil in the old rut of winter road, Haplomitrium hookeri, Lophoziopsis excisa, Scapania parvifolia, etc. were found. Liverworts on the banks of brooks and rocky substrates reach a special abundance and diversity (Fig. 2). On soil on brooks and rivers banks in the forest belt Jungermannia borealis, Plagiochila porelloides, Solenostoma obovatum, Scapania crassiretis, S. mucronata, S. paludicola and S. rufidula form a minute and small continuous cover. On soil on brooks banks in the tundra belt Calycularia laxa, Cryptocolea imbricata, Gymnomitrion concinnatum, Scapania crassiretis, S. irrigua, S. kaurinii, S. paludicola, S. scand$i c a$, etc. grow on soil in large amounts. On the rock-fields in dry niches between the stones Tetralophozia setiformis, Barbilophozia barbata, Radula complanata and Trilopho- zia quinquedentata develop a continuous population up to 100 sq. cm or 1 sq. m and Scapania sphaerifera, Lophoziopsis excisa, and L. longidens up to $1 \mathrm{~cm}$. Also on the rock-fields in places of late snow melting occur Marsupella emarginata, Scapania curta and $S$. spitsbergensis forming a continuous patches up to $10 \mathrm{~cm}$, while Jungermannia borealis, Lophoziopsis jurensis, Sphenolobus minutus and Trilophozia quinquedentata up to $1 \mathrm{~cm}$. On scree, among small stones, small (up to $10 \mathrm{~cm}$ ) and minute (up to $1 \mathrm{~cm}$ ) cover is characteristic for Sphenolobus saxicola, Lophoziopsis excisa, and Cephaloziella varians. High species diversity is noted on wet cliff habitats. Marsupella emarginata forms extensive continuous carpets (more than 1 sq. m), Marchantia romanica - large patches (up to 1 sq. m), Anthelia juratzkana, Cephalozia bicuspidata, Diplophyllum taxifolium, Gymnomitrion corallioides, Lophoziopsis excisa, etc. have smaller cover, and Barbilophozia sudetica, Marsupella boeckii, Pseudotritomaria heterophylla, etc. - minute (up to $1 \mathrm{~cm}$ ) cover. Mannia fragrans and Frullania inflata were found only on dry cliffs.

\section{SPECIES LIST}

In the present list liverwort taxa are arranged alphabetically. The list is annotated in the following order: species name, abbreviations of structures connected with reproduction, if present, in parentheses: m. pl. - male plant, f. pl. - female plant, andr. - androecia; per. - perianthia, spor. - mature sporophytes, gem. - gemmae; elevation range in brackets ( $\mathrm{m}$ alt.); collecting sites (1-10, cf. Fig. 1); substrate, habitats and growth pattern. The following scale was used for determination of growth pattern: few plants (FP), minute continuous cover (M) up to 1 sq. cm, small continuous cover (S) - up to 100 sq. $\mathrm{cm}$, large (L) - up to 1 sq. $\mathrm{m}$ and extensive continuous cover (E) - more than 1 sq. m. All specimens are deposited in the Herbarium of Institute for Biological Problems of Cryolithozone SB RAS, Yakutsk (SASY).

Aneura pinguis (L.) Dumort. - [1200 m]. 5. On soil: brook bank. FP.

Anthelia juratzkana (Limpr.) Trevis. (spor.) - [1200-1600 m]. 5. On soil, stones covered with soil: tundra, rock outcrops, brook banks. FP, M, S.

Asterella saccata (Wahlenb.) A. Evans - [550-620 m]. 1, 7. On soil: steppes. FP, L.

Barbilophozia barbata (Schmidel ex Schreb.) Loeske - [300$1050 \mathrm{~m}$ ]. 3, 8, 10. On soil, stones covered with soil: Larix forests, rock-fields. FP, S, L.

B. sudetica (Nees ex Huebener) L. Söderstr., De Roo et Hedd. (andr., gem.) - [1200-1600 m]. 5. On soil, stones covered with soil: rock outcrops, rock-fields, brook banks. FP, M. 
Blasia pusilla L. - [550-650 m]. 9, 10. On soil: horsetail, moss shrub post-ice community. FP.

Blepharostoma trichophyllum (L.) Dumort. - [1050 m]. 10. On stones covered with soil: rock-fields. FP.

Calycularia laxa Lindb. et Arnell (spor.) - [1400 m]. 5. On soil: tundra, brook banks. FP, S.

Calypogeia muelleriana (Schiffn.) Müll.Frib. - [500-850 m] 3, 6. On soil, on and among Sphagnum: Larix forest, rock outcrops. FP, S.

Cephalozia bicuspidata (L.) Dumort. (spor.) - [500-1400 m] $3,5,6,10$. On soil, on and among Sphagnum, stones covered with soil: Larix forests, tundra, rock outcrops, rockfields, brook and river bank, moss community on disturbed soil. FP, M, S, L.

Cephaloziella polystratosa (R.M. Schust. et Damsh.) Konstant. (spor.) - [850 m]. 3. On rotten wood: brook bank. M.

C. varians (Gottsche) Steph. (spor., gem.) - [550-1600 m]. 3, $5,6,10$. On soil, stones covered with soil: Salix shrubs, moss community on old rut winter roads, rock-fields, rock outcrops, screes, brook banks. FP, M.

Cryptocolea imbricata R.M. Schust. - [1400 m]. 5. On soil: brook banks. FP, S.

Diplophyllum taxifolium (Wahlenb.) Dumort. (gem.) - [1200 $1550 \mathrm{~m}$ ]. 5. On soil, stones covered with soil: tundra, rock outcrops, brook banks. FP, M, S.

Frullania inflata Gottsche - $[550 \mathrm{~m}]$. 8. On stones covered with soil: rock outcrops in steppe. M.

Fuscocephaloziopsis pleniceps (Austin) Váňa et L. Söderstr. - [500 m]. 8. On soil: brook bank. FP.

Gymnomitrion concinnatum (Lightf.) Corda (spor.) - [1200$1550 \mathrm{~m}$ ]. 5. On soil, stones covered with soil: tundra, rock outcrops, brook banks. FP, S, L.

G. corallioides Nees - [1350-1600 m]. 5. On soil, stones covered with soil: lichen tundra, rock outcrops. S.

Haplomitrium hookeri (Lyell ex Sm.) Nees - [650 m]. 10. On soil: moss community on old rut winter road. FP.

Isopaches bicrenatus (Schmidel ex Hoffm.) H. Buch (spor., gem.) - [500-1350 m]. 3, 5, 6, 10. On soil: Larix forest, Pinus pumila shrubs, lichen tundra, brook bank. FP, M.

Jungermannia borealis Damsh. et Váňa (andr.) - [850-1050 $\mathrm{m}$ ]. 3, 10. On soil, stones covered with soil: brook bank, rock-fields. M.

Lophocolea minor Nees - [800 m]. 10. On rotten wood: brook bank. FP.

Lophozia cf. savicziae Schljakov (spor., gem.) - [500-1400 m]. 5, 6, 10. On soil, stones covered with soil: rock-fields, rock outcrops, brook banks. M, S.

L. cf. silvicola H. Buch (gem.) - [500 m]. 6. On soil: Larix forest. FP.

L. cf. ventricosa (Dicks.) Dumort. s.l. (gem.) - [500-850 m]. 3, 6. On soil, on and among Sphagnum: Larix forest, grass mire. FP, S.

L. cf. wenzelii (Nees) Steph. (gem.) - [1300 m]. 5. On stones covered with soil: rock outcrops. FP.

Lophoziopsis excisa (Dicks.) Konstant. et Vilnet (spor., gem.) - [700-1600 m]. 3, 5, 6, 10. On soil, stones covered with soil, rotten wood: lichen tundra, moss community on disturbed soil, rock-fields, rock outcrops, screes, brook bank. FP, M, S.

L. jurensis (Meyl. ex Müll. Frib.) Mamontov et Vilnet (gem.) $-[500 \mathrm{~m}] .8$. On soil: rock-fields. M.

L. longidens (Lindb.) Konstant. et Vilnet (andr., gem.) - [850 m]. 10. On stones covered with soil: rock-fields. M.
L. polaris (R.M. Schust.) Konstant. et Vilnet (gem.) - [12001400 m]. 5. On soil: brook banks. FP.

Mannia fragrans (Balb.) Frye et L. Clark (spor.) - [550-700 $\mathrm{m}] .7,8,10$. On soil, stones covered with soil: steppes, rock outcrops. FP, L.

Marchantia polymorpha L. subsp. polymorpha (m., f. pl.,) [770 m]. 4. On soil: brook bank. L.

M. polymorpha L. subsp. ruderalis Bischl. et Boissel.-Dub. (gem.) - [550 m]. 9. On soil: horsetail community. FP.

M. romanica (Radian) D.G. Long, Crand.-Stotl., L.L. Forrest et J.C. Villarreal - [1600 m]. 5. On soil: brook bank. L.

Marsupella boeckii (Austin) Lindb. ex Kaal. (andr., per.) - [1300 $\mathrm{m}]$. 5. On stones covered with soil: rock outcrops. M.

M. emarginata (Ehrh.) Dumort. (spor.) - [1050-1600 m]. 5, 10. On soil, stones covered with soil: rock outcrops, rock-fields, brook bank. M, S, E.

M. sprucei (Limpr.) Bernet (spor.) - [1400 m]. 5. On soil: tundra. FP.

Mesoptychia rutheana (Limpr.) L. Söderstr. et Váňa - [800 m]. 10. On soil: brook bank. FP.

Neoorthocaulis binsteadii (Kaal.) L. Söderstr., De Roo et Hedd. - [850 m]. 3. On and among Sphagnum: Larix forest. FP.

Plagiochila porelloides (Torr. ex Nees) Lindenb. - [300-1050 $\mathrm{m}] .8,10$. On soil, stones covered with soil: rock-fields, brook banks. FP, S.

Pseudotritomaria heterophylla (R.M. Schust.) Konstant. et Vilnet (gem.) - [1100-1200 m]. 2, 5. On soil, stones covered with soil: rock outcrops, brook bank. M.

Ptilidium ciliare (L.) Hampe - [300-1050 m]. 3, 8, 10. On soil, stones covered with soil, rotten wood: Larix forests, rockfields, brook banks. FP, S, L.

Radula complanata (L.) Dumort. (spor.) - [850 m]. 10. On stones covered with soil: rock-fields. S.

Riccardia chamedryfolia (With.) Grolle - [1200 m]. 5. On soil: brook bank. FP.

Riccia sorocarpa Bisch. - [550-620 m]. 1, 7, 9. On soil: steppes, horsetail. FP.

Scapania crassiretis Bryhn (gem.) - [550-1400 m]. 2, 5, 6. On soil, stones covered with soil: tundra, rock outcrops, brook and river banks. FP, $\mathrm{S}$.

S. curta (Mart.) Dumort. (andr., per., immature spor., gem.) $[300 \mathrm{~m}] .8$. On stones covered with soil: rock-fields. S.

$S$. hyperborea Jørg. - [1050 m]. 10. On stones covered with soil: rock-fields. FP.

S. irrigua (Nees) Nees (gem.) - [1200 m]. 5. On soil: brook bank. S.

S. kaurinii Ryan (spor.) - [1300-1400 m]. 5. On soil, stones covered with soil: rock outcrops, brook banks. FP, S.

S. microdonta (Mitt.) Müll. Frib. - [1050-1300 m]. 5, 10. On stones covered with soil: rock-fields. FP.

S. mucronata H. Buch (andr., gem.) - [300 m]. 8. On soil: brook bank. M.

S. obcordata (Berggr.) S.W. Arnell (gem.) - [800 m]. 10. On soil: brook bank. M.

S. paludicola Loeske et Müll. Frib. (andr.) - [500-1200 m]. 3, $5,6,8$. On soil: grass mire, brook and river banks. FP, S.

S. parvifolia Warnst. (andr., per., gem.) - [500-850 m]. 3, 6 . On soil: moss communities on disturbed soil, Larix forest, rock outcrops. FP, M.

S. rufidula Warnst. - [500-1400 m]. 5, 7. On soil: brook and river bank. FP, M.

S. scandica (Arnell et H. Buch) Macvicar (andr., gem.) - [1200 m]. 5. On soil: brook bank. S. 
S. sphaerifera H. Buch et Tuom. (gem.) - [1050-1300 m]. 5, 10. On stones covered with soil: rock-fields. FP, M.

S. spitsbergensis (Lindb.) Müll. Frib. (spor., gem.) - [1050$1550 \mathrm{~m}] .5,10$. On stones covered with soil: rock outcrops, rock-fields. FP, S.

Schistochilopsis opacifolia (Culm. ex Meyl.) Konstant. (spor., gem.) - [1200-1400 m]. 5. On soil: brook banks. FP.

Schljakovia kunzeana (Huebener) Konstant. et Vilnet - [550 m]. 8. On soil: brook bank. FP.

Solenostoma obovatum (Nees) C. Massal. (per.: paroicous) [550 m]. 6. On soil: river bank. M.

Sphenolobus minutus (Schreb. ex D. Crantz) Berggr. - [500$1400 \mathrm{~m}] .3,5,8,10$. On soil, stones covered with soil: tundra, rock-fields. FP, M.

S. saxicola (Schrad.) Steph. - [900-1550 m]. 3, 5, 10. On soil, stones covered with soil: rock outcrops, rock-fields, screes, brook bank. FP, S.

Tetralophozia setiformis (Ehrh.) Schljakov - [900-1600 m]. 3, 5,10 . On soil, stones covered with soil: rock-fields, rock outcrops, lichen tundra. FP, M, S, L.

Trilophozia quinquedentata (Huds.) Bakalin - [500-1600 m]. 2, 5, 8, 10. On soil, stones covered with soil: rock-fields, rock outcrops, brook banks. FP, M, S.

\section{DISCUSSION}

In total, 65 species and 1 subspecies of liverworts were recorded in the study area. Marsupella sprucei is recorded for the first time for Yakutia. This diversity is rather high, although the area is quite xeric. It is comparable with the local liverworts flora of Upper Kyubyume River (65 species, Sofronova \& Potemkin, 2016), Algama River (69 species, Sofronova, 2013), Orulgan Sis Reserve (73 species, Sofronova \& Sofronov, 2012). At the same time, it should be noted that almost all the diversity of species was found along the banks of watercourses, in wet niches of rock-fields and in moist, shaded cracks of rock. Calcium was probably present in the soil, which added seven calciphilous species in studied flora: Asterella saccata, Cryptocolea imbricata, Frullania inflata, Mannia fragrans, Marchantia romanica, Mesoptychia rutheana, Pseudotritomaria heterophylla. In plant communities, a very small number of liverworts have been collected. Only 9 species were found in larch forests: Barbilophozia barbata, Calypogeia muelleriana, Cephalozia bicuspidata, Isopaches bicrenatus, Lophozia ventricosa, Ptilidium ciliare, Scapania parvifolia, Lophozia silvicola, and Neoorthocaulis binsteadii. Of these, only the last two species were collected only here. In the mountain tundra, 12 liverworts are noted: Anthelia juratzkana, Calycularia laxa, Cephalozia bicuspidata, Diplophyllum taxifolium, Gymnomitrion concinnatum, G. corallioides, Isopaches bicrenatus, Lophoziopsis excisa, Scapania crassiretis, Sphenolobus minutus, Tetralophozia setiformis, Marsupella sprucei, and only the last species was collected only here. Asterella saccata and Mannia fragrans are limited in its distribution only to steppes in the study area. Most of the species, including the rare ones, were collected on open slope of Tas-Kys- tabyt Mt. (Fig. 1) on banks of small brook, numerous rock outcrops and rock-fields: Calycularia laxa, Cryptocolea imbricata, Marchantia romanica, Marsupella boeckii, Pseudotritomaria heterophylla, Scapania kaurinii, S. rufidula, and S. sphaerifera (Fig. 2). Another rare species - Haplomitrium hookeri-was found in the moss community on an old rut of a winter road.

\section{ACKNOWLEDGEMENTS}

I am grateful to Margarita Fedorovna Osipova for arranging a very interesting visit to the Tas-Kystabyt Range and provided great help while conducting the field work. I also thank Dr. J. Shevock for correcting English of the manuscript. This study was done in the course of Project VI.52.1.8. (Fundamental and applied aspects of biodiversity studies of plants of North and Central Yakutia (0376-2018-0001; AAAA-A17-117020110056-0) and partly supported by RFBR №16-04-01156 and Program of Fundamental Research of the Russian Academy of Sciences I.2.41 "Biodiversity of Natural Systems and Biological Resources of Russia". Theme: "Biological Diversity and Dynamics of the plant world of Russia" AAAA-A18-118032890101-8.

\section{LITERATURE CITED}

[AFONINA, O.M. \& J. DUDA] АФОНИНА О.М., Й. ДУДА. 1980. К флоре печеночных мхов среднего течения р. Индигирки. - [To the flora of liverworts of the middle reaches river Indigirka] Новости систематики низших растений [Novosti Sistematiki Nizshikh Rastenij] 17: 211-215.

[IMAEV, V.S., L.P. IMAEVA \& B.M. KOZMICH] ИMAEB В.С., Л.П. ИМАЕВА, Б.М. КОЗЬМИЧ. 2000. Сейсмотектоника Якутии. [Seismotectonics of Yakutia] M.: IEOC [M.: GEOS]: $227 \mathrm{pp}$.

IVANOVA, E.I., E.A. IGNATOVA, V.G. ISAKOVA, I.A. BALAKIREV, O.I. KUZNETSOVA \& M.S. IGNATOV. 2018. Moss flora of Ust-Nera region in the upper course of Indigirka River, East Yakutia. - Arctoa 27(1): $18-28$

[IZYUMENKO, S.A. (ed.)] ИЗЮМЕНКО С.А. (отв. ред.). 1966. Справочник по климату СССР. Вып. 24. Якутская АССР. Ч. 2. Температура воздуха и почвы. - [Meteorological Handbook of USSR. Vol. 24. Yakutian ASSR. Part 2. The temperature of air and soil] J., Гидрометеоиздат [Leningrad, Gidrometeoizdat], 398 pp.

[IZYUMENKO, S.A. (ed.)] ИЗЮМЕНКО С.А. (отв. ред.). 1968. Справочник по климату СССР. Вып. 24. Якутская АССР. Ч. 4. Влажность воздуха, атмосферные осадки, снежный покров. - [Meteorological Handbook of USSR. Vol. 24. Yakutian ASSR. Part 4. The humidity, precipitation, snow cover] Л., Гидрометеоиздат [Leningrad, Gidrometeoizdat], $187 \mathrm{pp}$.

SOFRONOVA, E.V. 2013. Liverworts of the Algama River Basin (Tokinsky Stanovik Range, South-Eastern Yakutia). - Arctoa 22: 139-144.

[SOFRONOVA, E.V. \& A.D. POTEMKIN] СОФРОНОВA E.В., А.Д. ПОТЕМКИН. 2016. Первые сведения о печеночниках (Marchantiophyta) восточного макросклона хребта Сунтар-Хаята (Восточная Якутия). - [First data on the liverwort flora of the eastern macroslope of the Suntar-Khayata Range (Eastern Yakutia)] Ботанический журнал [Botanicheskij Zhurnal] 101(5): 581-591.

[SOFRONOVA, E.V. \& R.R. SOFRONOV] COФРOHOBA E.B., P.P. СОФРОНОВ. 2012. Печеночники ресурсного резервата «Орулган Сис» (хребет Орулган, Северо-Восточная Якутия). - [The liverworts of the Orulgan Sis Resource Reserves (Orulgan Ridge, North-Easytern Yakutia)] Ботанический журнал [Botanicheskij Zhurnal] 97(4): 487-496. 